\title{
Litter Controls Earthworm-Mediated Carbon and Nitrogen Transformations in Soil from Temperate Riparian Buffers
}

\author{
Maria Kernecker, ${ }^{1}$ Joann K. Whalen, ${ }^{1}$ and Robert L. Bradley ${ }^{2}$ \\ ${ }^{1}$ Department of Natural Resource Sciences, McGill University, Macdonald Campus, 21111 Lakeshore Road, \\ Ste-Anne-de-Bellevue, QC, Canada H9X 3 V9 \\ ${ }^{2}$ Département de biologie, Université de Sherbrooke, 2500 Boulevard de l'Université, Sherbrooke, QC, Canada J1K 2R1
}

Correspondence should be addressed to Joann K. Whalen; joann.whalen@mcgill.ca

Received 14 June 2014; Revised 18 August 2014; Accepted 18 August 2014; Published 14 September 2014

Academic Editor: Rafael Clemente

Copyright (c) 2014 Maria Kernecker et al. This is an open access article distributed under the Creative Commons Attribution License, which permits unrestricted use, distribution, and reproduction in any medium, provided the original work is properly cited.

\begin{abstract}
Nutrient cycling in riparian buffers is partly influenced by decomposition of crop, grass, and native tree species litter. Nonnative earthworms in riparian soils in southern Quebec are expected to speed the processes of litter decomposition and nitrogen (N) mineralization, increasing carbon $(\mathrm{C})$ and $\mathrm{N}$ losses in gaseous forms or via leachate. A 5-month microcosm experiment evaluated the effect of Aporrectodea turgida on the decomposition of 3 litter types (deciduous leaves, reed canarygrass, and soybean stem residue). Earthworms increased $\mathrm{CO}_{2}$ and $\mathrm{N}_{2} \mathrm{O}$ losses from microcosms with soybean residue, by $112 \%$ and $670 \%$, respectively, but reduced $\mathrm{CO}_{2}$ and $\mathrm{N}_{2} \mathrm{O}$ fluxes from microcosms with reed canarygrass by $120 \%$ and $220 \%$, respectively. Litter type controlled the $\mathrm{CO}_{2}$ flux (soybean $\geq$ deciduous-mix litter $=$ reed canarygrass $>$ no litter) and the $\mathrm{N}_{2} \mathrm{O}$ flux (soybean $\geq$ no litter $\geq$ reed canarygrass $>$ deciduous-mix litter). However, in the presence of earthworms, there was a slight increase in $\mathrm{C}$ and $\mathrm{N}$ gaseous losses of $\mathrm{C}$ and $\mathrm{N}$ relative to their losses via leachate, across litter treatments. We conclude that litter type determines the earthworm-mediated decomposition effect, highlighting the importance of vegetation management in controlling $\mathrm{C}$ and $\mathrm{N}$ losses from riparian buffers to the environment.
\end{abstract}

\section{Introduction}

Plant litter quality is known to affect several soil properties and ecosystem functions such as nutrient cycling [1], net primary productivity [2], and ecosystem carbon storage [3]. Likewise, the effect of litter quality on soil greenhouse gas (GHG) emissions is a growing concern that requires more empirical data-driven research. For example, it has been long known that litter quality (i.e., lignin concentration) is related to short-term soil $\mathrm{CO}_{2}$ emissions, but the rate of these emissions may vary according to both biotic [4] and abiotic [5] factors. Furthermore, the long-term effects of litter quality on $\mathrm{CO}_{2}$ release are less obvious [6]. While some studies have looked at peat quality on the release of gases other than $\mathrm{CO}_{2}$ [7], surprisingly few studies have looked at the effects of litter quality from trees and agronomic crops on gases such as $\mathrm{N}_{2} \mathrm{O}$ or $\mathrm{CH}_{4}$.

It could be assumed that plants producing litter that is palatable for soil fauna might favor the production of certain
GHG. For example, earthworms not only are expected to accelerate short-term $\mathrm{CO}_{2}$ release but also have been related to an increase in soil $\mathrm{N}_{2} \mathrm{O}$ emissions [8]. It is postulated that this is due to anaerobic microsites within the earthworm gut that promote denitrifying bacteria and $\mathrm{N}_{2} \mathrm{O}$ production [9]. In a microcosm study, Bradley et al. [8] found that litter from the legume alfalfa (Medicago sativa) increased earthworm biomass relative to litter from trees, shrubs, or nonlegume agronomic plants. Also, they found that earthworm-litter mixtures that included alfalfa litter produced more $\mathrm{N}_{2} \mathrm{O}$ than microcosms amended with less palatable litter types. However, it is unknown whether this relationship between litter quality, earthworms, and $\mathrm{N}_{2} \mathrm{O}$ production can be generalized across other leguminous and nonleguminous plant species.

The fact that earthworms accelerate nutrient cycling [10, 11], increase $\mathrm{NO}_{3}$ availability, and improve soil structure has led to the general view that nonnative earthworms generally improve soil quality in agricultural fields. Some have raised 
the question, however, of whether exotic earthworms also have negative environmental impacts on ecosystem services in previously earthworm-free regions [12-14]. For example, riparian buffer strips in agricultural systems take up excess, mobile nutrients such as $\mathrm{NO}_{3}$ before they enter waterways that border agricultural fields. Thus, the presence of earthworms in riparian buffer strips may lead to a decline in the rate of $\mathrm{NO}_{3}$ reduction to gaseous $\mathrm{N}_{2} \mathrm{O}$, while also increasing leaching of $\mathrm{DOC}$ and $\mathrm{NO}_{3}$ due to preferential flow pathways resulting from their burrowing activities. In southern Quebec (Canada), there currently is a debate as to how best to manage riparian areas. Some have proposed establishing a vegetative buffer with forage graminoids [15], like reed canarygrass (Phalaris arundinacea), whose fibrous root systems efficiently remove soil $\mathrm{NO}_{3}$. Others highlight the value of unmanaged, native vegetation like deciduous forests along rivers for intercepting excess nutrients from agriculture, preventing erosion, and providing habitat for a number of species [16, 17]. What is often observed, however, is that common crop species such as soybean (Glycine max) are cultivated up to the margin of the bordering waterways. Given that earthworms were introduced to Southern Quebec only a few 100 years ago and have not become established ubiquitously, it would be timely to test for litter quality $\times$ earthworm interactions on GHG emissions and DOC and $\mathrm{NO}_{3}$ leaching, in the context of riparian buffer management as the range of nonnative earthworm communities is expected to expand.

Soil nutrient concentration is affected by the decomposition of plant litter but also by season. Higher soil nutrient concentrations during spring have been well recorded [18], and so it is reasonable to assume that nutrient losses during decomposition of plant residue from riparian buffers into adjacent waterways or the atmosphere via gases may furthermore be accentuated by episodic precipitation that is characteristic of spring weather patterns. For example, in temperate regions, higher temperatures in early spring promote denitrification and the loss of some soluble $\mathrm{N}$ via leaching [19], instigating a flush of nutrients from previously senesced plant residues and lysed microbial cells in riparian soils [20]. Therefore, fluctuating soil moisture and temperature generally cause some of the greatest rates of decomposition and $\mathrm{C}$ and $\mathrm{N}$ losses [21].

Here we report on a microcosm study where we tested the effects and the interactions of 3 litter types and earthworms on soil $\mathrm{CO}_{2}$ and $\mathrm{N}_{2} \mathrm{O}$ production and on dissolved organic carbon (DOC) and $\mathrm{NO}_{3}$ leaching under simulated springlike temperature and precipitation patterns when maximum losses of $\mathrm{C}$ and $\mathrm{N}$ from riparian soils are expected to occur $[22,23]$. The soil was collected from a riparian buffer, and the litter types specifically reflected a choice of riparian plant species that grow or could be cultivated in riparian buffers in southern Quebec.

\section{Materials and Methods}

2.1. Soil, Litter, and Earthworms. Soil was collected in October 2009 from the top $25 \mathrm{~cm}$ of a mixed grass-legume hay field that was fertilized with manure in a riparian buffer along the Riviere-aux-Brochets, in southern Québec,
Canada $\left(45^{\circ} 08^{\prime} \mathrm{N}, 73^{\circ} 03^{\prime} \mathrm{W}\right)$. It was thoroughly hand-sorted to remove earthworms, roots, and rocks, sieved through $6 \mathrm{~mm}$ and stored at $4^{\circ} \mathrm{C}$. A week before the experiment began soil was air-dried to facilitate mixing and homogenizing. The soil was classified as a Gleysol, specifically a Ste. Rosalie clay loam of the Richelieu series [24]. It contained $422 \mathrm{~g} \mathrm{~kg}^{-1}$ of sand and $315 \mathrm{~g} \mathrm{~kg}^{-1}$ of clay with $15.6 \mathrm{~g}$ organic $\mathrm{C} \mathrm{kg}^{-1}$ and had pH 6.2.

Plant litter was collected in late October 2009. Senescent soybean residue (Glycine $\max$ ) remaining on the soil surface after harvest was taken from an agricultural field adjacent to the Riviere-aux-Brochets. Live reed canarygrass leaves (Phalaris arundinacea) were cut from plants growing in the riparian buffer between a cultivated agricultural field and the river. Recently fallen deciduous forest litter was collected from the forest floor within a forest remnant patch along the riparian buffer. This litter was composed predominantly of sugar maple (Acer saccharum), beech (Fagus grandifolia), and yellow birch (Betula alleghaniensis) leaves and hereafter is referred to as deciduous-mix litter. All litter was dried at $70^{\circ} \mathrm{C}$ for $48 \mathrm{~h}$ and ground to $2 \mathrm{~mm}$ prior to the experiment. The physical condition and chemical characteristics of litter are described in Table 1.

Endogeic earthworms (Aporrectodea turgida) were collected in November 2009 by hand-sorting soil from the experimental farm at the Macdonald Campus of McGill University in Ste-Anne-de-Bellevue, Québec, Canada $\left(45^{\circ} 28^{\prime} \mathrm{N}\right.$, $\left.73^{\circ} 45^{\prime} \mathrm{W}\right)$. They were kept in $37 \mathrm{~L}$ culture boxes at $12^{\circ} \mathrm{C}$ for 3 months. Boxes contained Chicot sandy loam soil (Luvisol) from the same farm and earthworms were initially fed fresh, roughly chopped clover (Trifolium repens) from the experimental farm and then with Magic worm food (Magic Products, Inc., Amherst Junction, Wisconsin, USA), every 3-7 d. Two days before the experiment began, adult and large juvenile earthworms were removed from culture boxes and placed on moistened Kimwipes to void their guts for $48 \mathrm{~h}$ at $15^{\circ} \mathrm{C}$.

2.2. Experimental Design. The experiment was a 5-monthlong microcosm experiment that began in February 2010. The design was a 2 -way factorial experiment (litter $\times$ earthworm). There were 4 litter treatments: soybean, reed canarygrass, deciduous-mix, and no litter and 2 earthworm treatments: endogeic earthworm and a no earthworm control. The 8 factorial treatments were repeated 4 times, for a total of 48 microcosms. Microcosms with endogeic earthworms had 5 individuals, which represent 637 individuals $\mathrm{m}^{-2}$ per microcosm. While this number is high, it is similar to some of the highest populations of approximately 530 individuals $\mathrm{m}^{-2}$ in riparian buffers of southern Québec (personal observation). Also, numbers as high as 553 individuals $\mathrm{m}^{-2}$ have been reported to survive in enclosures with manipulated earthworm populations in agroecosystems in southern Quebec [27]. This number of earthworms was selected for the study to maximize litter decomposition and $\mathrm{C}$ and $\mathrm{N}$ mineralization and therefore clearly isolate the earthworm effect.

Microcosms were polyvinyl chloride (PVC) pipes, $35 \mathrm{~cm}$ tall with $10 \mathrm{~cm}$ internal diameter. The bottoms were capped with PVC caps containing 37 holes (evenly spaced, $4 \mathrm{~mm}$ 
TABLE 1: Characteristics of litter added to microcosms containing riparian soil from along the Pike River in southern Québec.

\begin{tabular}{lccccc}
\hline Litter type & $\begin{array}{c}\text { Organic C } \\
\left(\mathrm{g} \mathrm{kg}^{-1}\right)^{1}\end{array}$ & $\begin{array}{c}\mathrm{N} \\
\left(\mathrm{g} \mathrm{kg}^{-1}\right)^{1}\end{array}$ & C-to-N ratio & AIS $^{2}$-to-N ratio & \\
\hline Soybean & 406 & 13 & 31 & 4.3 & Quality class $^{4}$ \\
Reed canarygrass & 451 & 10 & 45 & 12.9 & Intermediate \\
Deciduous mix & 475 & 14 & 34 & 8.3 & Intermediate \\
\hline
\end{tabular}

Determined with a Flash EA 1112 CN analyzer (Carlo Erba, Milan, Italy).

${ }^{2}$ Acid insoluble substances.

${ }^{3}$ Fiber was analyzed using the gravimetric method [25], using an Ankom Fiber Analyzer (Ankom Technology, Fairport, NY).

${ }^{4}$ Organic residue quality classification based on Palm et al. [26].

diameter). Caps were permanently affixed to PVC pipes with silicon. A funnel was then attached to the bottom of each cap with silicon to facilitate collection of leachate from the microcosm. Plastic mesh $(1.5 \mathrm{~mm})$ was placed in the bottom of the microcosm to prevent soil and earthworm loss, and the microcosm was hand-packed with $2.5 \mathrm{~kg}$ of moist soil (dry weight basis) at a bulk density of $1.2 \mathrm{~g} \mathrm{~cm}^{-3}$ to a depth of $30 \mathrm{~cm}$. Preweighed earthworms were placed on the soil surface; after they had burrowed into the soil, $25 \mathrm{~g}$ of litter (dry weight basis) was placed on the soil surface and moistened with $150 \mathrm{~mL}$ water. Microcosms were kept in an environment cabinet at $12^{\circ} \mathrm{C}$ with constant $(60 \%)$ humidity and no light for the duration of the experiment. Each microcosm was watered weekly with $150 \mathrm{~mL}$ of distilled tap water, which is equivalent to $19 \mathrm{~mm}$ of precipitation, the average weekly spring precipitation in southern Québec from March to June based on long-term (1971-2000) weather data [28].

2.3. Headspace Sampling and Analysis for $\mathrm{CO}_{2}$ and $\mathrm{N}_{2} \mathrm{O}$. Each microcosm was sampled on the first day of the experiment and then at 2, 4, 6, 8, 10,12,14,16, and 20 wks (9 sampling dates) during the incubation. At each sampling event, the microcosm was watered and then the incubator temperature was raised to $20^{\circ} \mathrm{C}$ for $24 \mathrm{~h}$ in order to stimulate the highest moments of nutrient loss from riparian soils. Since these conditions would stimulate short-term nutrient fluxes, these values should not be extrapolated to riparian soils under field conditions. Incubator ambient air was sampled after closing the microcosms $(t=0)$ and the microcosm headspace with a vented lid, equipped with septa, was sampled with a gastight syringe after $24 \mathrm{~h}(t=24)$. Headspace gas samples were injected into preevacuated $20 \mathrm{~mL}$ exetainers (Labco, High Wycombe, UK) for storage (1 wk) until analysis for $\mathrm{CO}_{2}$ and $\mathrm{N}_{2} \mathrm{O}$ on a gas chromatograph (Hewlett-Packard 5890 Series II, Hewlett-Packard Co., Avondale, PA). Fluxes of $\mathrm{CO}_{2}$ and $\mathrm{N}_{2} \mathrm{O}$ were calculated following conversion of gas concentrations from ppm to $\mathrm{mg} \mathrm{L}^{-1}$ according to the equation from Holland et al. [29]. The $\mathrm{CO}_{2}-\mathrm{C}$ and $\mathrm{N}_{2} \mathrm{O}-\mathrm{N}$ fluxes $\left(\mathrm{mg} \mathrm{m}^{-2} \mathrm{~h}^{-1}\right)$ were then calculated according to Hutchinson and Mosier [30]. Taking 2 measurements in $24 \mathrm{~h}$ may have led to an overestimation of gas fluxes. However, our study focused on overall effect patterns, which we were able to observe due to the same treatment of all experimental units.

2.4. Leachate and Soil Sample Analyses. At each sampling date, an acid-washed plastic bottle was placed under each microcosm funnel to collect leachate for $\mathrm{NO}_{3}$ and DOC analysis, which was filtered through $5-10 \mu \mathrm{m}$ medium porosity filter paper (Fisherbrand Q5, Thermo Fisher Scientific, Ottawa, ON) and stored at $4^{\circ} \mathrm{C}$ until analysis. Three $10 \mathrm{~g}$ soil samples were removed from the top of each microcosm using a hand-held core $(2 \mathrm{~cm}$ diameter and approximately $4 \mathrm{~cm}$ deep): one was used to evaluate soil moisture and the second was prepared for $\mathrm{NH}_{4}$ and $\mathrm{NO}_{3}$ analysis with the $0.5 \mathrm{M} \mathrm{K}_{2} \mathrm{SO}_{4}$ extraction method [31] and the third for microbial biomass $\mathrm{C}$ and $\mathrm{N}$ determination by the chloroform fumigation-direct extraction method, according to Voroney et al. [32], followed by persulfate digestion to convert dissolved organic nitrogen from microbial biomass $\mathrm{N}(\mathrm{MBN})$ to $\mathrm{NO}_{3}{ }^{-}$[33]. The $\mathrm{NH}_{4}$ and $\mathrm{NO}_{3}$ concentration in leachates and unfumigated and fumigated extracts was analyzed with a Lachat Quik Chem Autoanalyzer (Lachat Instruments, Milwaukee, WI, USA). The MBN was calculated as [(total extractable $\mathrm{N}$ after fumigationtotal extractable $\mathrm{N}$ before fumigation) $/ k_{\mathrm{EN}}$ ], where $k_{\mathrm{EN}}$ is the extraction coefficient of 0.54 . The DOC in leachates and unfumigated and fumigated soil extracts was determined on a Shimadzu TOC-V carbon analyzer (Shimadzu Corporation, Kyoto, Japan). The microbial biomass C (MBC) concentration was calculated as [(fumigated soil extract-unfumigated soil extract) $/ k_{\mathrm{EC}}$ ] where $k_{\mathrm{EC}}$ is the extraction coefficient 0.45 [32].

2.5. Light Fraction Analysis. After 20 wks, microcosms were sampled destructively to recover earthworms, which were then counted and weighed (after clearing the gut for $48 \mathrm{~h}$ ) to determine earthworm weight gain or loss within each microcosm. Soil from each microcosm was homogenized and a $40 \mathrm{~g}$ subsample was taken for light fraction (LF) determination following the method of Gregorich et al. [34], which involved shaking the soil in sodium polytungstate with a specific gravity of $\rho=1.7$ and then allowing soil minerals to settle for $48 \mathrm{~h}$. The LF was aspirated from the solution above the soil minerals, washed from the vacuum flask and funnel onto a 5-10 $\mu \mathrm{m}$ filter paper with $75 \mathrm{~mL} \mathrm{CaCl}_{2}$ followed by $75 \mathrm{~mL}$ distilled water, and then dried $\left(60^{\circ} \mathrm{C}\right.$ for $\left.48 \mathrm{~h}\right)$ and analyzed for total C (assumed to equal organic C) with a Flash EA 1112 NC Soils Analyzer (Carlo Erba, Milan, Italy).

2.6. Statistical Analysis. Data were tested for normality using the Shapiro-Wilk test. Initial and final earthworm biomass were tested with a paired $t$-test to compare earthworm biomass before and after the experiment, allowing us to measure earthworm survival and validate our experimental 
TABLE 2: Earthworm biomass, number of individuals, and percentage change after 20 wks in soil microcosms with riparian litter. Values are the mean \pm standard error $(n=4)$. There was no significant change in biomass or numbers.

\begin{tabular}{|c|c|c|c|c|c|c|}
\hline \multirow[b]{2}{*}{$\begin{array}{l}\text { Litter } \\
\text { treatment }\end{array}$} & \multicolumn{3}{|c|}{$\begin{array}{c}\text { Earthworm biomass } \\
\text { ( } g \text { fresh weight per microcosm) }\end{array}$} & \multicolumn{3}{|c|}{$\begin{array}{l}\text { Earthworm numbers } \\
\text { (individuals per microcosm) }\end{array}$} \\
\hline & Initial & Final & Change in biomass (\%) & Initial & Final & Change in individuals (\%) \\
\hline Soybean & 1.8 & $2.7 \pm 0.2$ & $54.6 \pm 37$ & 5 & $5.7 \pm 0.2$ & 0.8 \\
\hline Reed canarygrass & 1.6 & $1.8 \pm 0.4$ & $25.1 \pm 33$ & 5 & $5.2 \pm 0.1$ & 0.3 \\
\hline Deciduous-mix & 2.2 & $2.7 \pm 0.3$ & $20.2 \pm 28$ & 5 & $6.2 \pm 0.1$ & 1.3 \\
\hline No litter & 1.4 & $1.3 \pm 0.6$ & $7.7 \pm 28$ & 5 & $6.5 \pm 0.2$ & 1.5 \\
\hline \multirow[t]{2}{*}{ Paired $t$-test } & $t$ & $\mathrm{DF}$ & $P$ value & & & \\
\hline & -1.5221 & 15 & 0.1488 & & & \\
\hline
\end{tabular}

setup [35]. The remaining $\mathrm{C}$ and $\mathrm{N}$ measurement data did not conform to assumptions of parametric tests, even after transformations, so we were unable to perform repeated measures analysis. Therefore, the data were pooled across 9 sampling dates and presented as the average $\mathrm{CO}_{2}-\mathrm{C}$ and $\mathrm{N}_{2} \mathrm{O}$ $\mathrm{N}$ fluxes, leachate $\mathrm{DOC}$ and $\mathrm{NO}_{3}$ concentrations, and soil $\mathrm{NH}_{4}, \mathrm{NO}_{3}, \mathrm{MBC}$, and $\mathrm{MBN}$ concentrations ( $n=144$ per treatment). The effects of litter, earthworms, and the litter $\times$ earthworm treatments (treated as a single independent variable) on the mean responses, along with $\mathrm{LF}-\mathrm{C}$ and \% soil moisture, were analyzed with the Kruskal-Wallis test (kruskal.test). Those variable which had observed differences higher than the reported critical value were considered statistically different at $\alpha=0.5$, warranting multiple comparisons. Multiple comparisons between means were done using the Dunn-Nemenyi procedure [36], with the function kruskalmc from the package pgirmess [37]. Finally, Spearman's rank correlation was used to evaluate the relationship between ancillary soil $\mathrm{C}$ and $\mathrm{N}$ measurements and $\mathrm{C}$ and $\mathrm{N}$ losses from microcosms with and without earthworms using the function cor.test. This allowed us to identify whether the effects of earthworms on leachate losses were negatively related to gaseous losses, and if the effect of earthworms on $\mathrm{N}$ losses was related to their effect on C. All tests were done using the $\mathrm{R}$ interface [38].

\section{Results}

3.1. Earthworm Survival, Moisture Conditions, and Light Fraction $C$. There was no change in endogeic earthworm biomass or survival among litter types during the $20 \mathrm{wks}$ study; no earthworms were found in control soils (Table 2). Mean soil moisture in microcosms ranged from $32.5 \%$ at the first sampling to $37.4 \%$ gravimetric soil moisture at the last sampling of the 20 wks study. Microcosms with reed canarygrass had higher mean soil moisture $(36.7 \%$ gravimetric soil moisture) than other litter treatments $(P=$ $0.0388)$. There was no difference between litter $\times$ earthworm interaction on mean soil moisture during the 20 wks study $(P=0.4848)$.

From visual observation, litter in microcosms with earthworms disappeared faster than in microcosms without earthworms. Soybean litter was the first to completely disappear from the soil surface and after 20 wks, there was no visible litter remaining of surface-applied litter in all microcosms and thus less than $1 \%$ of litter $\mathrm{C}$ was recovered as LF-C. The $\%$ litter recovered as LF-C after 20 wks was controlled by litter type $(P=0.0395)$, with higher LF-C content $(0.26 \%)$ in reed canarygrass-amended microcosms than the deciduous-mix treatment $(0.14 \%)$, but there was no effect of earthworms and litter $\times$ earthworm treatments on LF-C (data not shown).

\subsection{Potential $C$ and $N$ Losses}

3.2.1. $\mathrm{CO}_{2}$ and $\mathrm{N}_{2} \mathrm{O}$ Gas Fluxes. Earthworms increased $\mathrm{CO}_{2}$ and $\mathrm{N}_{2} \mathrm{O}$ losses from microcosms with soybean residue, by $112 \%$ and $670 \%$, respectively, but reduced $\mathrm{CO}_{2}$ and $\mathrm{N}_{2} \mathrm{O}$ fluxes from microcosms with reed canarygrass by $120 \%$ and $220 \%$, respectively. Mean $\mathrm{CO}_{2}$ fluxes over 20 wks were affected significantly by the litter $\times$ earthworm interaction $(P<0.0001)$. Soybean-amended microcosms with earthworms had higher mean $\mathrm{CO}_{2}$ than reed canarygrass-amended microcosms with and without earthworms (Figure 1). Soybean-amended microcosms without earthworms had higher mean $\mathrm{CO}_{2}$ fluxes than the microcosms without litter and those amended with reed canarygrass and containing earthworms. Litter $(P<0.0001)$ and earthworms $(P=0.0230)$ each affected mean $\mathrm{CO}_{2}$ fluxes such that the mean $\mathrm{CO}_{2}$ fluxes were the greatest in microcosms with soybean $>$ reed canarygrass $=$ deciduous-mix litter $>$ no litter (Figure 1).

The litter $\times$ earthworm interaction was also significant for the mean $\mathrm{N}_{2} \mathrm{O}$ fluxes $(P<0.0001)$. In soybean-amended microcosms, earthworms significantly increased mean $\mathrm{N}_{2} \mathrm{O}$ fluxes compared to treatments without earthworms. The soybean-amended microcosms with earthworms also had higher mean $\mathrm{N}_{2} \mathrm{O}$ fluxes than microcosms amended with deciduous-mix litter, no litter, and reed canarygrass, all with and without earthworms (Figure 2). Deciduous-mix litter without earthworms had significantly lower mean $\mathrm{N}_{2} \mathrm{O}$ fluxes than reed canarygrass-amended microcosms without earthworms. Reed canarygrass-amended microcosms with earthworms had lower mean $\mathrm{N}_{2} \mathrm{O}$ fluxes than those without earthworms. Mean $\mathrm{N}_{2} \mathrm{O}$ fluxes over the 20 wks experiment were affected significantly $(P<0.0001)$ by litter and were the greatest in microcosms with soybean $>$ no litter $=$ reed canarygrass $\geq$ deciduous-mix litter. Earthworms significantly increased mean $\mathrm{N}_{2} \mathrm{O}$ fluxes as well $(P=0.0004$, Figure 2$)$. 

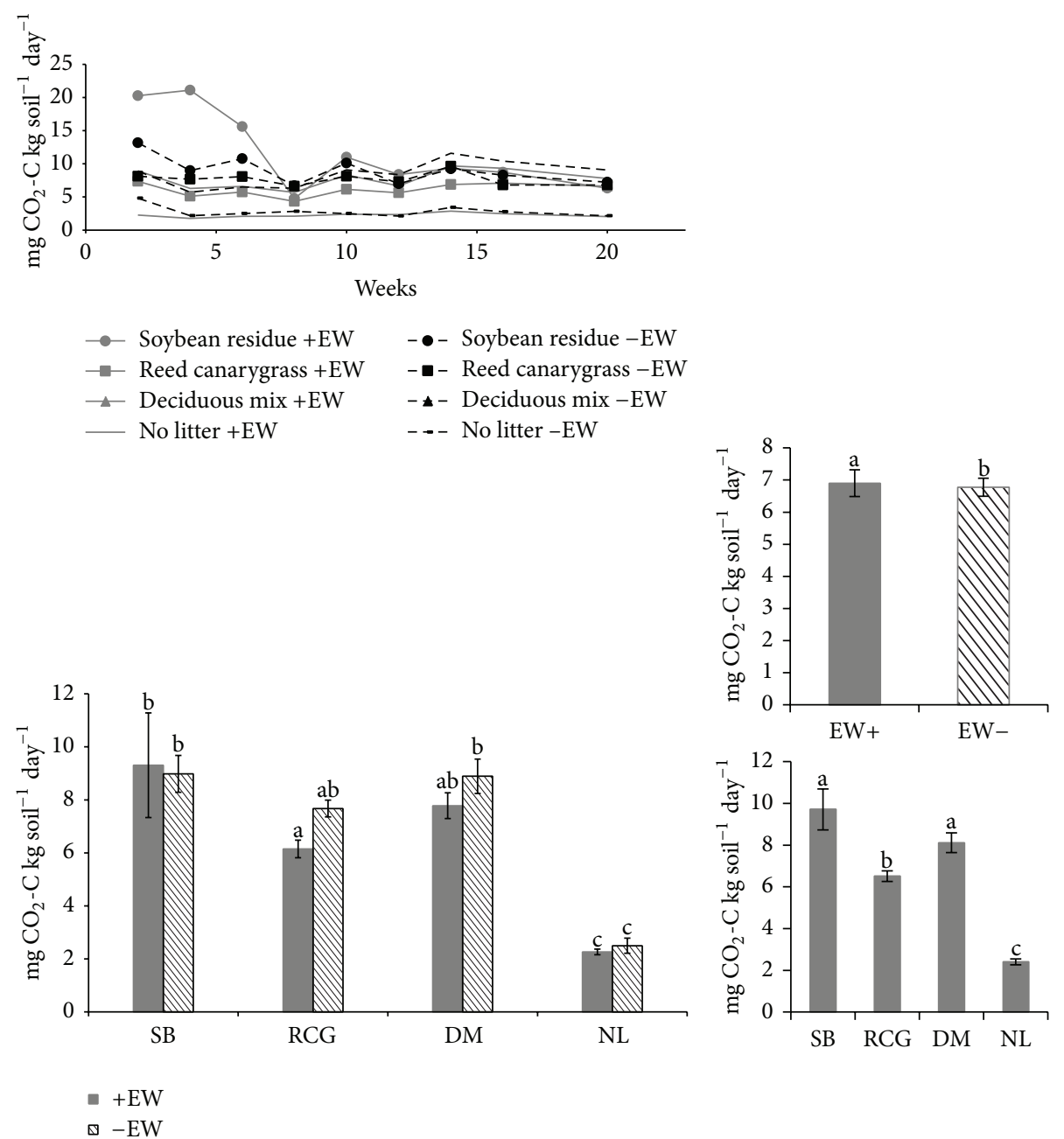

FIGURE 1: Mean $\mathrm{CO}_{2}$ fluxes over time from each treatment combination (litter $\times$ earthworm) from microcosms with riparian soil over 20 wks. Bar graphs indicate mean $\mathrm{CO}_{2}$ fluxes averaged from nine sampling dates, according to litter $\times$ earthworm treatments $(n=36)$, earthworms $(n=144)$, and litter effects $(n=60)$. Litter treatments are labeled according to no litter $(\mathrm{NL})$, soybean (SB), reed canarygrass $(\mathrm{RCG})$, or deciduous-mix litter (DM). Error bars represent the standard error of the mean. Lower-case letters ( $a, b$, and $c)$ represent differences due to the litter $\times$ earthworm interaction $(P<0.05$, Kruskal-Wallis test).

3.2.2. $\mathrm{DOC}$ and $\mathrm{NO}_{3}$ Concentration in Leachate. The mean DOC concentration in leachate ranged from $13.9 \mathrm{mg} \mathrm{L}^{-1}$ in the litter-free microcosms to $38.7 \mathrm{mg} \mathrm{L}^{-1}$ in earthworm-free microcosms with deciduous-mix litter. Litter, earthworm, and the litter $\times$ earthworm interaction affected mean DOC concentration in leachate $(P<0.05)$ from microcosms during the 20 wks experiment. The highest DOC losses were in microcosms without earthworms, and the lowest DOC losses were from soybean-amended microcosms with earthworms and litter-free microcosms (Table 3 ). There was a significant effect of the litter $\times$ earthworm interaction and litter on mean $\mathrm{NO}_{3}$ concentrations in leachate. The highest mean $\mathrm{NO}_{3}$ concentration, $41.7 \mathrm{mg} \mathrm{NO}_{3} \mathrm{~L}^{-1}$, was from microcosms with soybean litter $x$ endogeic earthworms (Table 3 ). Microcosms with deciduous-mix had the lowest $\mathrm{NO}_{3}$ losses.

3.3. Soil $C$ and $N$ Pools in Soil Microcosms. The litter $\times$ earthworm interaction and litter significantly affected soil $\mathrm{NH}_{4}$, $\mathrm{NO}_{3}, \mathrm{MBC}$, and $\mathrm{MBN}$ concentrations in soil extracts.
Soybean-amended microcosms had the greatest mean soil $\mathrm{NH}_{4}$ and $\mathrm{NO}_{3}$ concentrations, particularly in the presence of earthworms (Table 4). Litter-free microcosms with earthworms had the lowest mean MBN concentration (Table 4). Similarly, litter-free microcosms had the lowest MBC compared to microcosms with litter. Mean MBN was the highest in microcosms amended with reed canarygrass without earthworms. Mean MBC was higher in microcosms with reed canarygrass $\times$ no earthworm and deciduous-mix $\times$ earthworms than in microcosms without litter (Table 4).

Correlation analysis tested the relationship between the different forms of $\mathrm{C}$ and $\mathrm{N}$ losses, as affected by both the presence and absence of earthworms. Results showed that in the presence of earthworms, $\mathrm{CO}_{2}$ flux was positively correlated with $\mathrm{NH}_{4}, \mathrm{MBC}$, and $\mathrm{MBN}$ concentrations, and leachate DOC, whereas $\mathrm{N}_{2} \mathrm{O}$ flux was positively correlated with $\mathrm{NO}_{3}$ concentrations in the soil and in the leachate (Table 5). In microcosms without earthworms, $\mathrm{CO}_{2}$ flux was positively correlated with soil $\mathrm{NH}_{4}, \mathrm{MBN}, \mathrm{MBC}$, and 

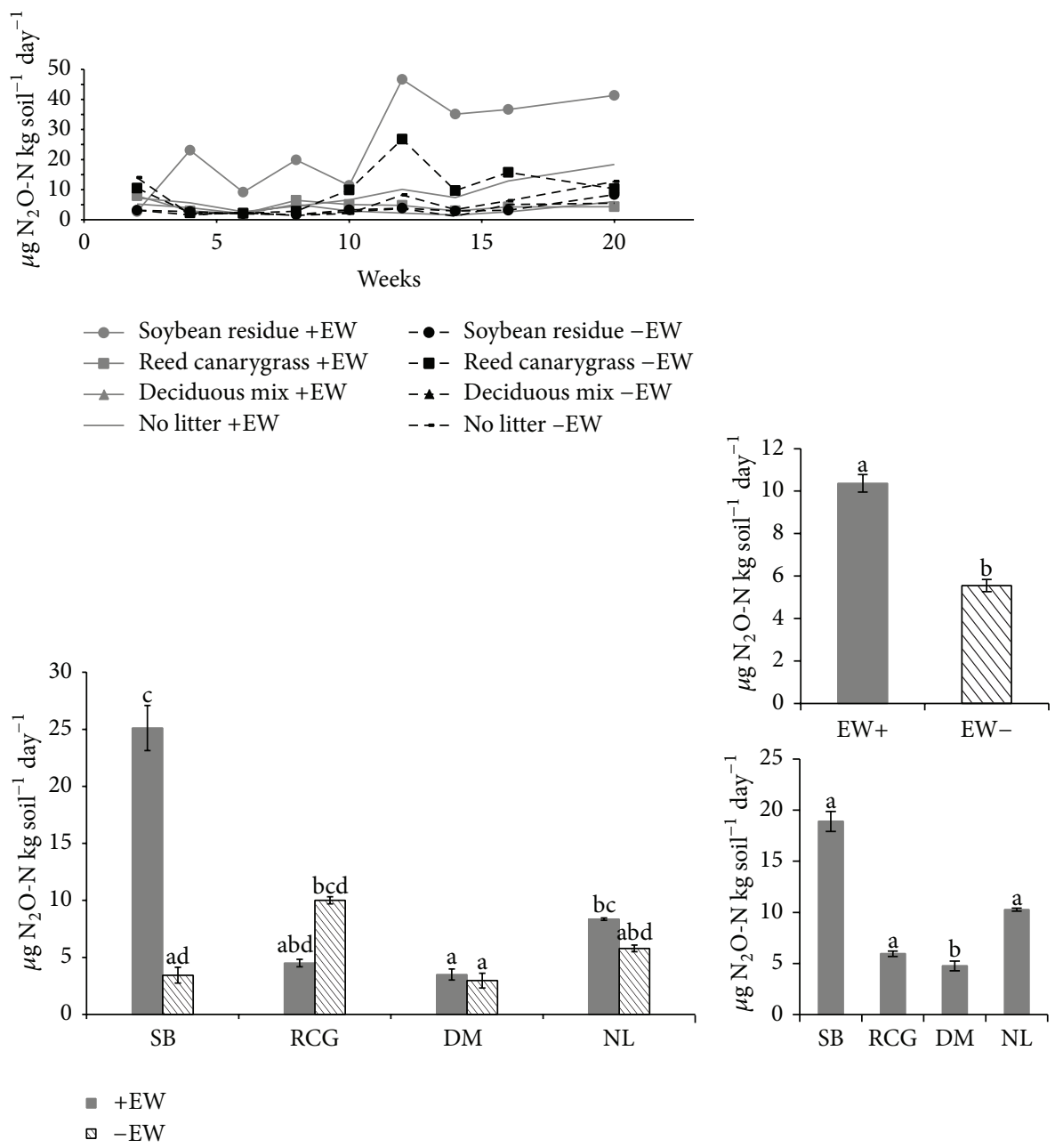

Figure 2: Mean $\mathrm{N}_{2} \mathrm{O}$ fluxes over time from each treatment combination (litter $\times$ earthworm) from microcosms with riparian soil over 20 wks. Bar graphs indicate mean $\mathrm{N}_{2} \mathrm{O}$ fluxes averaged from nine sampling dates, according to litter $\times$ earthworm treatments $(n=36)$, earthworms $(n=144)$, and litter effects $(n=60)$. Litter treatments are labeled according to no litter (NL), soybean (SB), reed canarygrass (RCG), or deciduous-mix litter (DM). Error bars represent the standard error of the mean. Lower-case letters (a, b, $c$, and d) represent differences due to the litter $\times$ earthworm interaction $(P<0.05$, Kruskal-Wallis test $)$.

soluble C losses. $\mathrm{N}_{2} \mathrm{O}$ was positively correlated with soil $\mathrm{NO}_{3}$ concentrations but not with $\mathrm{NO}_{3}$ losses in leachate (Table 6). Earthworms tended to stimulate $\mathrm{C}$ loss via $\mathrm{CO}_{2}$ flux and reduced leachate DOC losses (Figure 3). They also promoted a shift towards $\mathrm{N}$ loss via $\mathrm{N}_{2} \mathrm{O}$ flux rather than leachate $\mathrm{NO}_{3}$ loss but increased $\mathrm{N}$ losses in both forms when compared to microcosms without earthworms (Figure 4).

\section{Discussion}

4.1. Endogeic Earthworms Affect Decomposition of Riparian Plant Residue. Overall, there was no difference in the LF$\mathrm{C}$ content in microcosms with and without earthworms, leading us to assume that earthworms initially accelerate decomposition of soybean residue but that, otherwise, they may not increase the total amount of organic matter that is decomposed and mineralized in the long term (Figure 1). Likewise, in their meta-analysis of earthworm effects on greenhouse gases, Lubbers et al. [9] found that while earthworms had a short-term effect on $\mathrm{CO}_{2}$ fluxes by stimulating microbial activity, their effect declined as the experimental period increased ( $>30$ days). Litter had a stronger effect on driving differences in both $\mathrm{LF}-\mathrm{C}$ and $\mathrm{CO}_{2}$. Higher LF-C in microcosms amended with reed canarygrass coincided with lower mean $\mathrm{CO}_{2}$ emissions, compared to microcosms amended with soybean, which had lower LF-C remaining, most likely due to greater overall decomposition. We therefore assume that litter quality determines the palatability of associated organic matter for endogeic earthworms and their subsequent influence on decomposition.

4.2. Endogeic Earthworms Affect $C$ and $N$ Losses. There was a marked effect of endogeic earthworms on $\mathrm{C}$ and $\mathrm{N}$ losses from microcosms amended with soybean (Figures 1-4). Our findings corroborate research by Bradley et al., [8], who found that soil amended with leguminous litter instigated greater $\mathrm{C}$ and $\mathrm{N}$ losses than other litter-amended soils, particularly in the presence of earthworms. However, while their study 
TABLE 3: Dissolved organic carbon (DOC) and nitrate $\left(\mathrm{NO}_{3}\right)$ from microcosms containing riparian soils. Values are the mean ( \pm standard error) of nine sampling dates $(n=144)$. Within a column, values followed by the same letter are not significantly different $(P<.05)$ according to Dunn-Nemenyi’s procedure for multiple comparisons.

\begin{tabular}{|c|c|c|c|c|}
\hline $\begin{array}{l}\text { Earthworm } \\
\text { treatment }\end{array}$ & $\begin{array}{c}\text { Litter } \\
\text { treatment }\end{array}$ & & & $\begin{array}{c}\mathrm{NO}_{3}-\mathrm{N} \\
\left.\text { (mg L } \mathrm{m}^{-1} \text { leachate }\right)\end{array}$ \\
\hline \multirow{4}{*}{ Earthworm } & Soybean & \multicolumn{2}{|c|}{$18.0 \pm 1.1^{\mathrm{c}}$} & $41.7 \pm 4.3^{\mathrm{d}}$ \\
\hline & Reed canarygrass & \multicolumn{2}{|c|}{$26.1 \pm 1.1^{\mathrm{a}}$} & $21.9 \pm 3.2^{\mathrm{abc}}$ \\
\hline & Deciduous mix & \multicolumn{2}{|c|}{$30.4 \pm 1.4^{\mathrm{ab}}$} & $11.3 \pm 2.4^{\mathrm{a}}$ \\
\hline & No litter & \multicolumn{2}{|c|}{$12.6 \pm 1.2^{\mathrm{c}}$} & $23.2 \pm 2.9^{\mathrm{bcd}}$ \\
\hline \multirow{4}{*}{ Control } & Soybean & \multicolumn{2}{|c|}{$31.0 \pm 2.0^{\mathrm{ab}}$} & $26.3 \pm 3.6^{\mathrm{cd}}$ \\
\hline & Reed canarygrass & \multicolumn{2}{|c|}{$27.5 \pm 1.5^{\mathrm{a}}$} & $19.0 \pm 1.7^{\mathrm{abc}}$ \\
\hline & Deciduous mix & \multicolumn{2}{|c|}{$38.7 \pm 1.7^{\mathrm{b}}$} & $13.4 \pm 2.5^{\mathrm{ab}}$ \\
\hline & No litter & \multicolumn{2}{|c|}{$16.4 \pm 0.7^{\mathrm{c}}$} & $18.0 \pm 1.8^{\mathrm{abc}}$ \\
\hline Kruskal-Wallis test & & $x^{2}$ & $\mathrm{df}$ & $P>\chi^{2}$ \\
\hline \multicolumn{5}{|l|}{ DOC } \\
\hline Litter & & 127.02 & 3 & $<0.0001$ \\
\hline Earthworm & & 22.52 & 1 & $<0.0001$ \\
\hline Litter $\times$ earthworm & & 26.3182 & 7 & $<0.0001$ \\
\hline Kruskal-Wallis test & & $\chi^{2}$ & $\mathrm{df}$ & $P>\chi^{2}$ \\
\hline \multicolumn{5}{|l|}{$\mathrm{NO}_{3}$} \\
\hline Litter & & 44.86 & 3 & $<0.0001$ \\
\hline Earthworm & & 1.76 & 1 & 0.1845 \\
\hline Litter $\times$ earthworm & & 50.67 & 7 & $<0.0001$ \\
\hline
\end{tabular}

TABLE 4: Mean soil $\mathrm{NH}_{4}, \mathrm{NO}_{3}, \mathrm{MBN}$, and $\mathrm{MBC}$ concentrations in microcosms containing riparian soils. Values are the average of nine sampling dates $(n=144)$. Within a column, values followed by the same letter are not significantly different $(\alpha=0.05)$ according to DunnNemenyi's procedure for multiple comparisons.

\begin{tabular}{|c|c|c|c|c|c|}
\hline Earthworm treatment & $\begin{array}{c}\text { Litter } \\
\text { treatment }\end{array}$ & $\begin{array}{c}\mathrm{NH}_{4} \\
\left(\mathrm{mg} \mathrm{kg}^{-1}\right)\end{array}$ & $\begin{array}{c}\mathrm{NO}_{3} \\
\left(\mathrm{mg} \mathrm{kg}^{-1}\right)\end{array}$ & $\begin{array}{c}\mathrm{MBN} \\
\left(\mathrm{mg} \mathrm{kg}^{-1}\right)\end{array}$ & $\begin{array}{c}\mathrm{MBC} \\
\left(\mathrm{mg} \mathrm{kg}^{-1}\right)\end{array}$ \\
\hline \multirow{4}{*}{ Earthworm } & Soybean & $20.1 \pm 7.2^{b}$ & $68.0 \pm 8.1^{\mathrm{b}}$ & $42.2 \pm 7.2^{\mathrm{ab}}$ & $461 \pm 44.6^{\mathrm{abc}}$ \\
\hline & Reed canarygrass & $6.7 \pm 3.1^{\mathrm{ab}}$ & $4.5 \pm 0.9^{\mathrm{a}}$ & $35.8 \pm 3.7^{\mathrm{a}}$ & $442 \pm 22.9^{\mathrm{ac}}$ \\
\hline & Deciduous mix & $1.4 \pm 0.2^{\mathrm{ab}}$ & $3.3 \pm 0.7^{\mathrm{a}}$ & $36.0 \pm 3.7^{\mathrm{a}}$ & $509 \pm 24.4^{\mathrm{a}}$ \\
\hline & Control & $1.1 \pm 0.1^{\mathrm{a}}$ & $23.4 \pm 0.8^{\mathrm{b}}$ & $19.3 \pm 2.0^{\mathrm{b}}$ & $297 \pm 15.6^{\mathrm{b}}$ \\
\hline \multirow{4}{*}{ Control } & Soybean & $1.6 \pm 0.35^{\mathrm{ab}}$ & $6.9 \pm 1.54^{\mathrm{a}}$ & $39.7 \pm 4.9^{\mathrm{a}}$ & $503 \pm 34.3^{\mathrm{abc}}$ \\
\hline & Reed canarygrass & $1.2 \pm 0.21^{\mathrm{a}}$ & $5.9 \pm 1.73^{\mathrm{a}}$ & $46.4 \pm 5.7^{\mathrm{a}}$ & $527 \pm 35.5^{\mathrm{a}}$ \\
\hline & Deciduous mix & $1.5 \pm 0.35^{\mathrm{ab}}$ & $4.5 \pm 1.24^{\mathrm{a}}$ & $38.4 \pm 4.5^{\mathrm{a}}$ & $468 \pm 28.2^{\mathrm{ac}}$ \\
\hline & Control & $0.9 \pm 0.21^{\mathrm{a}}$ & $21.2 \pm 2.34^{\mathrm{b}}$ & $29.8 \pm 4.7^{\mathrm{ab}}$ & $315 \pm 13.3^{\mathrm{bc}}$ \\
\hline \multirow[t]{4}{*}{ Kruskal-Wallis test } & & $P>\chi^{2}$ & $P>\chi^{2}$ & $P>\chi^{2}$ & $P>\chi^{2}$ \\
\hline & Litter & 0.0005 & $<.0001$ & $<.0001$ & $<.0001$ \\
\hline & Earthworm & 0.1043 & 0.0209 & 0.2405 & 0.6124 \\
\hline & Litter $\times$ Earthworm & 0.0012 & $<.0001$ & 0.0004 & $<.0001$ \\
\hline
\end{tabular}

used an anecic species, Lumbricus terrestris, we used endogeic earthworms in our study since these species like $A$. turgida were the most abundant species in temperate riparian soils (Quebec: [8]; Wisconsin: Costello and Lamberti, [39]). Through their different feeding and burrowing habits, anecic species have different effects on $\mathrm{C}$ and $\mathrm{N}$ losses from soils [40], which may not be relevant to riparian soils. Endogeic earthworms consume large amounts of soil organic matter in riparian soils, and the quality of the organic matter in these soils is controlled by vegetation in these locations [41]. However, endogeic earthworms generally do not feed upon material with high recalcitrant component concentration [42-44], which may explain their effect on $\mathrm{C}$ and $\mathrm{N}$ losses from microcosms amended with soybean residue compared to the other litter treatments. The soybean residues we used were collected for the experiment from a field, where the residues had likely undergone some predecomposition, compared to reed canarygrass residues, which were cut fresh.

We found that earthworm presence tends to increase soluble nutrient losses via leachate. In microcosms without litter but with earthworms, there were higher concentrations of $\mathrm{NO}_{3}$ lost, likely due to earthworm burrows, compared 
TABLE 5: Correlations between $\mathrm{C}$ and $\mathrm{N}$ losses via gaseous flux or in leachates and ancillary soil measurements, averaged from measurements $(n=144)$ taken at regular intervals during a 20 wks incubation study from microcosms filled with riparian soil with earthworms. Values are Spearman's rank order coefficients $(\rho)$, with $*, * *$, and $* * *$ indicating significant correlations at $P<0.05,0.01$, and 0.001 , respectively, and NS = nonsignificant correlation.

\begin{tabular}{|c|c|c|c|c|c|c|c|c|}
\hline & $\mathrm{CO}_{2}$ flux & $\mathrm{N}_{2} \mathrm{O}$ flux & Soil $\mathrm{NH}_{4}$ & Soil $\mathrm{NO}_{3}$ & Soil MBN & Soil MBC & Leachate DOC & Leachate $\mathrm{NO}_{3}$ \\
\hline $\mathrm{CO}_{2}$ flux & 1.0000 & & & & & & & \\
\hline $\mathrm{N}_{2} \mathrm{O}$ flux & -0.06 & 1.0000 & & & & & & \\
\hline Soil $\mathrm{NH}_{4}$ & $0.31^{* * *}$ & -0.07 & 1.0000 & & & & & \\
\hline Soil $\mathrm{NO}_{3}$ & -0.14 & $0.54^{* * *}$ & 0.15 & 1.0000 & & & & \\
\hline Soil MBN & $0.36^{* * *}$ & 0.06 & -0.03 & -0.12 & 1.0000 & & & \\
\hline Soil MBC & $0.19^{* *}$ & -0.15 & 0.06 & $-0.30^{* * *}$ & $0.28^{* * *}$ & 1.0000 & & \\
\hline Leachate DOC & $0.52^{* * *}$ & $-0.43^{* *}$ & 0.07 & $-0.58^{* * *}$ & $0.19^{*}$ & $0.27^{* * *}$ & 1.0000 & \\
\hline Leachate $\mathrm{NO}_{3}$ & -0.05 & $0.31^{* * *}$ & 0.15 & $0.26^{* * *}$ & $-0.30^{* * *}$ & $-0.22^{* *}$ & $-0.22^{* * *}$ & 1.0000 \\
\hline
\end{tabular}

TABLE 6: Correlations between $\mathrm{C}$ and $\mathrm{N}$ losses via gaseous flux or in leachates and ancillary soil measurements, averaged from measurements $(n=144)$ taken at regular intervals during a 20 wks incubation study from microcosms filled with riparian soil without earthworms. Values are Spearman's rank order coefficients $(\rho)$, with $*, * *$, and $* * *$ indicating significant correlations at $P<0.05,0.01$, and 0.001 , respectively, and NS = nonsignificant correlation.

\begin{tabular}{|c|c|c|c|c|c|c|c|c|}
\hline & $\mathrm{CO}_{2}$ flux & $\mathrm{N}_{2} \mathrm{O}$ flux & Soil $\mathrm{NH}_{4}$ & Soil $\mathrm{NO}_{3}$ & Soil MBN & Soil MBC & Leachate DOC & Leachate $\mathrm{NO}_{3}$ \\
\hline $\mathrm{CO}_{2}$ flux & 1.0000 & & & & & & & \\
\hline $\mathrm{N}_{2} \mathrm{O}$ flux & 0.00 & 1.0000 & & & & & & \\
\hline Soil $\mathrm{NH}_{4}$ & $0.25^{* * *}$ & -0.08 & 1.0000 & & & & & \\
\hline Soil $\mathrm{NO}_{3}$ & $-0.46^{* * *}$ & $0.18^{*}$ & -0.08 & 1.0000 & & & & \\
\hline Soil MBN & $0.19^{*}$ & $0.45^{* * *}$ & 0.02 & -0.02 & 1.0000 & & & \\
\hline Soil MBC & $0.24^{* * *}$ & -0.04 & 0.08 & -0.17 & $0.26^{* * *}$ & 1.0000 & & \\
\hline Leachate DOC & $0.53^{* * *}$ & $-0.23^{* * *}$ & $0.24^{* * *}$ & $-0.34^{* * *}$ & 0.12 & 0.14 & 1.0000 & \\
\hline Leachate $\mathrm{NO}_{3}$ & 0.04 & -0.02 & -0.07 & -0.20 & $-0.25^{* * *}$ & $-0.13^{* *}$ & -0.23 & 1.0000 \\
\hline
\end{tabular}

to the microcosms without litter and without earthworms. Although there was no litter available for nitrogen mineralization, endogeic earthworms fed on the soil, likely increasing mineralization of the associated organic matter, leading to higher $\mathrm{NO}_{3}$ lost through their burrows. Anecic earthworm burrows are large and vertical and have marked effects on $\mathrm{NO}_{3}$ leaching through the soil [13], but burrows from endogeic earthworms facilitate greater volumes of water to leach through soil profiles [45]. This may contribute to observations made in a previous study that found that in riparian forests endogeic earthworms increased both $\mathrm{NH}_{4}$ and $\mathrm{NO}_{3}$ leaching from soil to the adjacent waterway [14]. Our results compliment this study by showing that $\mathrm{N}$ losses via leachate are specific to earthworm and litter interactions.

\subsection{Litter Quality Drives the Earthworm Effect on Gaseous} $C$ and $N$ Losses. Litter quality, defined here by the acid insoluble substances to nitrogen (AIS:N) ratio and degree of predecomposition, controlled the effect that earthworms had on $\mathrm{C}$ and $\mathrm{N}$ transformations in microcosms with litter-amended riparian soil-particularly during simulated spring-like weather conditions. Higher soil $\mathrm{NH}_{4}$ and $\mathrm{NO}_{3}$ concentrations in soybean-amended microcosms highlight the fact that soybean residue is more easily decomposed than deciduous forest mix and reed canarygrass litter. This is attributed to the consistent availability and turnover of substrates in soybean litter to support a larger microbial population and their metabolic processes (Table 4, Figure 2), as evidenced by the higher $\mathrm{CO}_{2}$ and $\mathrm{N}_{2} \mathrm{O}$ fluxes from the soybean-amended microcosms. Labile $\mathrm{C}$ compounds influence $\mathrm{CO}_{2}$, DOC, and $\mathrm{MB}$ concentrations primarily, whereas the litter $\mathrm{N}$ content influences $\mathrm{NH}_{4}$ and $\mathrm{NO}_{3}$ concentrations in soil since $\mathrm{MBN}$ dynamics are related stoichiometrically to the $\mathrm{MBC}$ concentration. Soybean litter is relatively $\mathrm{C}$ and $\mathrm{N}$-rich (i.e., higher quality $\mathrm{C}$ substrate), which explains higher $\mathrm{MB}$ and $\mathrm{CO}_{2}$ release, since the $\mathrm{N}$-rich residues that were added lead to a priming effect that caused soil organic carbon to break down [46]. On the other hand, earthworms reduced $\mathrm{CO}_{2}$ and $\mathrm{N}_{2} \mathrm{O}$ fluxes in reed canarygrass-amended microcosms compared to soybean-amended microcosms, probably because reed canarygrass was less palatable to earthworms and less readily degraded by soil microorganisms due to its lower litter quality. This is consistent with Lubbers et al. [9] who reported that earthworms increase $\mathrm{N}_{2} \mathrm{O}$ fluxes from mesocosms as a function of soil and substrate quality.

The effect of litter on controlling $\mathrm{N}_{2} \mathrm{O}$ fluxes via denitrification may be further explained by patterns we observed between control microcosms and those amended with both deciduous-mix and reed canarygrass. In the control microcosms, without litter and without earthworms, soil $\mathrm{NO}_{3}$ concentrations were a tenth of the concentrations measured in microcosms with earthworms and soybean. However, it is notable that the $\mathrm{NO}_{3}$ concentrations in microcosms amended with reed canarygrass and deciduous-mix litter, both with 


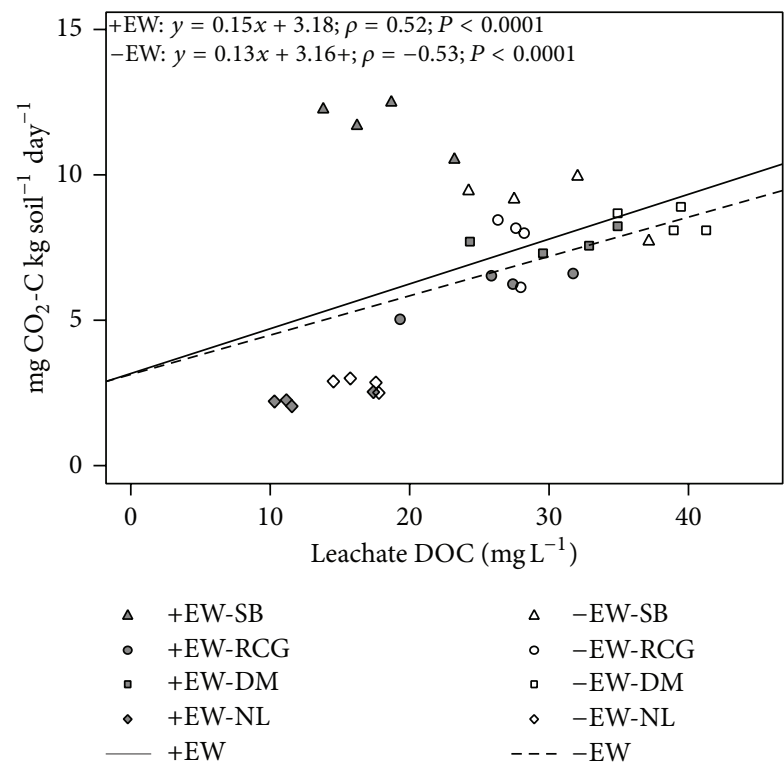

FIGURE 3: Scatter plot showing the functional relationship between $\mathrm{CO}_{2}$ flux and DOC concentration in leachate. Each point is the mean of 9 measurements taken of 1 of the 4 replicates during a 20 wks incubation study from microcosms filled with riparian soil that had earthworms present (EW, $n=36$ ) or no earthworms (NW, $n=144$ ) and received no litter (NL), soybean (SB), reed canarygrass (RCG), or deciduous-mix litter (DM) as the litter source. The linear equation and standard error of the estimated slope of the line describe the functional relationship for EW and NW treatments, across litter types. The strength of the relationship is given as Spearman's rank correlation coefficient $(\rho)$ and significance of each relationship $(P)$.

and without earthworms, were lower than the concentration of $\mathrm{NO}_{3}$ in control microcosms. This could be due to the immobilization of available $\mathrm{N}$ caused by deciduous-mix and reed canarygrass litter, since plant $\mathrm{C}$ controls immobilization [47]. Accordingly, MBC tended to be higher in those microcosms, suggesting $\mathrm{C}$ limitation for $\mathrm{N}$ cycling, and, as a result, lower rates of denitrification.

In the presence of earthworms, the mean $\mathrm{N}_{2} \mathrm{O}$ flux was positively correlated with soil $\mathrm{NH}_{4}$ and $\mathrm{NO}_{3}$ concentrations, implying that both $\mathrm{NH}_{4}$ and $\mathrm{NO}_{3}$ are likely substrates for $\mathrm{N}_{2} \mathrm{O}$ production because of ammonia oxidation in the nitrification pathway or $\mathrm{NO}_{3}$ reduction through denitrification. Both nitrification and denitrification can lead to $\mathrm{N}_{2} \mathrm{O}$ fluxes from earthworm-worked soil in plant-free microcosms [48], similar to the design used in this study. Although such microcosm designs do not capture the complexity of environmental factors present in the field, in particular, the relationship between nutrient loss and reabsorption via roots, we are able to observe patterns and isolate the effect of earthworms. The $\mathrm{N}_{2} \mathrm{O}$ fluxes from microcosms with unplanted riparian soil in this study are likely representative of $\mathrm{N}_{2} \mathrm{O}$ fluxes in the field for a brief period in the spring when earthworms are active and contributing to $\mathrm{N}$ mineralization from litter, but vegetation is still dormant or growing too slowly to use soil mineral $\mathrm{N}$ effectively. Peak nitrogen uptake or

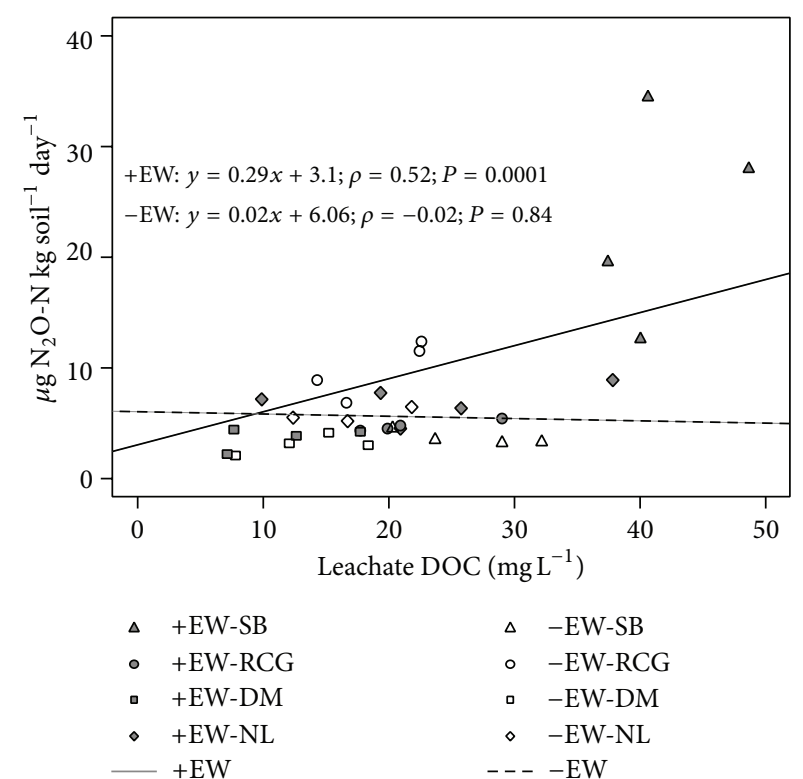

FIGURE 4: Scatter plot showing the functional relationship between $\mathrm{N}_{2} \mathrm{O}$ flux and $\mathrm{NO}_{3}$ concentration in leachate. Each point is the mean of 9 measurements taken of 1 of the 4 replicates during a $20 \mathrm{wks}$ incubation study from microcosms filled with riparian soil that had earthworms present (EW, $n=36$ ) or no earthworms (NW, $n=36$ ) and received no litter (NL), soybean (SB), reed canarygrass (RCG), or deciduous-mix litter (DM) as the litter source. The linear equation and standard error of the estimated slope of the line describe the functional relationship for EW and NW treatments, across litter types. The strength of the relationship is given as Spearman's rank correlation coefficient $(\rho)$ and significance of each relationship $(P)$.

reabsorption typically does not occur until during late spring or early summer, indicated by the highest plant shoot $\mathrm{N}$ concentrations in temperate, deciduous vegetation [18].

\subsection{Litter and Earthworms Interactively Control the Balance} of Gaseous to Leachate Losses. Most interestingly, the patterns of mean $\mathrm{DOC}$ and $\mathrm{NO}_{3}$ concentrations in leachate in relation to gaseous losses additionally support that there are litter and earthworm-specific relationships that control C and $\mathrm{N}$ losses from riparian soils. While earthworm presence reduced DOC loss from all microcosms, litter defined the amount of $\mathrm{CO}_{2}$ lost. The presence of earthworms, specifically, tended to result in a slight shift of the Closs towards $\mathrm{CO}_{2}$ flux, relative to DOC in leachate (Figure 3), although this depended largely on the litter type. Higher DOC in leachate from microcosms without earthworms suggests that earthworms stimulated denitrifier use of soluble C. Accordingly, in soils with earthworms, DOC concentration in the leachate was positively correlated with MBC and MBN (Table 5), compared to soils without earthworms, where there was no correlation between these factors (Table 6). Since denitrification requires $\mathrm{NO}_{3}$ and soluble C, we preclude that lower DOC leaching from soils was due to the greater denitrifier activity. This is supported by the fact that in the presence of earthworms, there was a significant shift in the fate of recently mineralized $\mathrm{N}$, which 
was more likely to be lost via $\mathrm{N}_{2} \mathrm{O}$ flux than remain in soil solution where it was susceptible to leaching.

\subsection{Experimental Conditions and Patterns of Earthworm and} Litter Effects. Our experimental setup is specifically representative of the humid temperate agricultural landscapes of southern Quebec, during spring, when nutrient losses from riparian buffers to aquatic ecosystems may be the greatest. We sought to study how nonnative earthworms may change the balance of nutrient losses from different types of riparian buffers. While our data shows interesting patterns, they cannot be extrapolated to the field. Soil $\mathrm{NO}_{3}$, leachate $\mathrm{NO}_{3}$, and $\mathrm{N}_{2} \mathrm{O}$ emissions from microcosms amended with soybean residue were all very high. Should such high concentrations of $\mathrm{NO}_{3}$ leach through the soil into aquatic ecosystems, they could contribute to higher $\mathrm{NO}_{3}$ in rivers and streams. Furthermore, our soil originated from a permanent pasture that received manure inputs, which provided a rich soil with already high levels of $\mathrm{N}$ that perhaps facilitated the high $\mathrm{N}$ losses we quantified. The surplus $\mathrm{NO}_{3}$ in soil was then either leached out or reduced to $\mathrm{N}_{2} \mathrm{O}$ via denitrification, which was not limited by $\mathrm{C}$. It was interesting that in the presence of earthworms, greater $\mathrm{NO}_{3}$ losses in the leachate from microcosms also resulted in higher $\mathrm{N}_{2} \mathrm{O}$ emissions. This relationship warrants further investigation, since we would suppose that greater $\mathrm{NO}_{3}$ losses in one direction (i.e., via leachate or gaseous reduction) could limit losses in the other direction due to substrate limitation for microbially mediated processes that are enhanced by earthworms.

\section{Conclusions}

We found that nonnative endogeic earthworms increase decomposition and $\mathrm{N}$-cycling in riparian soils amended with soybean residue and that soils amended with deciduous-mix and reed canarygrass have slower turnover of $\mathrm{C}$ and $\mathrm{N}$ both with and without earthworms during spring-like conditions. These results underline the important role that riparian buffer vegetation plays in the $\mathrm{C}$ and $\mathrm{N}$ cycles in riparian soils where nonnative earthworm communities dominated by endogeic species are well established. Perennial grasses and native deciduous forest produce litter and organic matter that decomposes slowly and is less palatable to earthworms, relative to soybean residues, and their breakdown will release modest amounts of soluble $\mathrm{C}$ and $\mathrm{N}$ into soil where it is susceptible to loss via leaching or from gaseous fluxes in the presence of earthworms. Deliberate planting of perennial grasses and maintenance of deciduous forest remnants in riparian buffers of southern Quebec could minimize C and $\mathrm{N}$ losses to the environment during the most vulnerable periods, in fall and spring when vegetation growth and plant uptake of $\mathrm{N}$ is negligible, but earthworms are active. It would be interesting to explore the effect of earthworms on $\mathrm{C}$ and $\mathrm{N}$ losses and the balance of gaseous to leachate losses in the field over the course of a whole growing season. Such research could lead to recommendations for agricultural producers to mitigating $\mathrm{C}$ and $\mathrm{N}$ losses from their fields and riparian buffers, particularly as the balance of gaseous to leachate losses may shift as nonnative earthworms become established in previously earthworm-free riparian areas.

\section{Conflict of Interests}

The authors declare that there is no conflict of interests regarding the publication of this paper.

\section{Acknowledgments}

The authors would like to thank Alicia Goodhue for laboratory assistance and Hélène Lalandefor analyzing soil extracts and leachate for mineral $\mathrm{N}$. Thanks are due to Centre SEVE and FQRNT for funding. The authors appreciate the comments by Anaïs Charles and three anonymous reviewers that substantially helped improve a previous version of this paper.

\section{References}

[1] G. T. Freschet, W. K. Cornwell, D. A. Wardle et al., "Linking litter decomposition of above- and below-ground organs to plant-soil feedbacks worldwide," Journal of Ecology, vol. 101, no. 4, pp. 943952, 2013.

[2] D. A. Wardle, R. D. Bardgett, R. M. Callaway, and W. H. van der Putten, "Terrestrial ecosystem responses to species gains and losses," Science, vol. 332, no. 6035, pp. 1273-1277, 2011.

[3] G. B. de Deyn, J. H. C. Cornelissen, and R. D. Bardgett, "Plant functional traits and soil carbon sequestration in contrasting biomes," Ecology Letters, vol. 11, no. 5, pp. 516-531, 2008.

[4] P. J. Hanson, N. T. Edwards, C. T. Garten, and J. A. Andrews, "Separating root and soil microbial contributions to soil respiration: a review of methods and observations," Biogeochemistry, vol. 48, no. 1, pp. 115-146, 2000.

[5] K. P. Wickland, J. C. Neff, and J. W. Harden, "The role of soil drainage class in carbon dioxide exchange and decomposition in boreal black spruce (Picea mariana) forest stands," Canadian Journal of Forest Research, vol. 40, no. 11, pp. 2123-2134, 2010.

[6] R. Gentile, B. Vanlauwe, and J. Six, "Litter quality impacts short- but not long-term soil carbon dynamics in soil aggregate fractions," Ecological Applications, vol. 21, no. 3, pp. 695-703, 2011.

[7] M. Reiche, G. Gleixner, and K. Küsel, "Effect of peat quality on microbial greenhouse gas formation in an acidic fen," Biogeosciences, vol. 7, no. 1, pp. 187-198, 2010.

[8] R. L. Bradley, J. Whalen, P.-L. Chagnon, M. Lanoix, and M. C. Alves, "Nitrous oxide production and potential denitrification in soils from riparian buffer strips: influence of earthworms and plant litter," Applied Soil Ecology, vol. 47, no. 1, pp. 6-13, 2011.

[9] I. M. Lubbers, K. J. van Groenigen, S. J. Fonte, J. Six, L. Brussaard, and J. W. Van Groenigen, "Greenhouse-gas emissions from soils increased by earthworms," Nature Climate Change, vol. 3, no. 3, pp. 187-194, 2013.

[10] F. Binet, L. Fayolle, and M. Pussard, "Significance of earthworms in stimulating soil microbial activity," Biology and Fertility of Soils, vol. 27, no. 1, pp. 79-84, 1998.

[11] W. H. van der Putten, J. M. Anderson, R. D. Bardgett et al., "The sustainable delivery of goods and services provided by soil biota," Sustaining Biodiversity and Ecosystem Services in Soils and Sediments, vol. 64, pp. 15-43, 2004. 
[12] R.-C. Le Bayon and F. Binet, "Earthworm surface casts affect soil erosion by runoff water and phosphorus transfer in a temperate maize crop," Pedobiologia, vol. 45, no. 5, pp. 430-442, 2001.

[13] J. Domínguez, P. J. Bohlen, and R. W. Parmelee, "Earthworms increase nitrogen leaching to greater soil depths in row crop agroecosystems," Ecosystems, vol. 7, no. 6, pp. 672-685, 2004.

[14] D. M. Costello and G. A. Lamberti, "Non-native earthworms in riparian soils increase nitrogen flux into adjacent aquatic ecosystems," Oecologia, vol. 158, no. 3, pp. 499-510, 2008.

[15] R. C. Schultz, T. M. Isenhart, W. W. Simpkins, and J. P. Colletti, "Riparian forest buffers in agroecosystems-lessons learned from the Bear Creek Watershed, Central Iowa, USA," Agroforestry Systems, vol. 61-62, no. 1-3, pp. 35-50, 2004.

[16] R. J. Naiman and H. Décamps, “The ecology of interfaces: riparian zones," Annual Review of Ecology and Systematics, vol. 28, pp. 621-658, 1997.

[17] P. Stoffyn-Egli and J. H. M. Willison, "Including wildlife habitat in the definition of riparian areas: the beaver (Castor canadensis) as an umbrella species for riparian obligate animals," Environmental Reviews, vol. 19, pp. 479-493, 2011.

[18] R. A. Farley and A. H. Fitter, "Temporal and spatial variation in soil resources in a deciduous woodland," Journal of Ecology, vol. 87, no. 4, pp. 688-696, 1999.

[19] M. M. Hefting, J.-C. Clement, P. Bienkowski et al., "The role of vegetation and litter in the nitrogen dynamics of riparian buffer zones in Europe," Ecological Engineering, vol. 24, no. 5, pp. 465482, 2005.

[20] C. N. Dahm, N. B. Grimm, P. Marmonier, H. M. Valett, and P. Vervier, "Nutrient dynamics at the interface between surface waters and groundwaters," Freshwater Biology, vol. 40, no. 3, pp. 427-451, 1998.

[21] K. B. Piatek, M. J. Mitchell, S. R. Silva, and C. Kendall, "Sources of nitrate in snowmelt discharge: evidence from water chemistry and stable isotopes of nitrate," Water Air and Soil Pollution, vol. 165, no. 1-4, pp. 13-35, 2005.

[22] M. E. McClain, E. W. Boyer, C. L. Dent et al., "Biogeochemical hot spots and hot moments at the interface of terrestrial and aquatic ecosystems," Ecosystems, vol. 6, no. 4, pp. 301-312, 2003.

[23] P. Vidon, C. Allan, D. Burns et al., "Hot spots and hot moments in riparian zones: potential for improved water quality management," Journal of the American Water Resources Association, vol. 46, no. 2, pp. 278-298, 2010.

[24] S. C. W. Group, "The Canadian system of soil classification," in Agriculture and Agri-Food Canada Publication, vol. 1646, NRC Research Press, Ottawa, Canada, 1998.

[25] H. Goering and P. Van Soest, "Forage fiber analyses (apparatus, reagents, procedures, and some applications)," in Agricultural Handbook no. 379, Agricultural Research Service, USDA, US Government Printing Office, Washington, DC, USA, 1970.

[26] C. A. Palm, K. E. Giller, P. L. Mafongoya, and M. J. Swift, "Management of organic matter in the tropics: translating theory into practice," Nutrient Cycling in Agroecosystems, vol. 61, no. 1-2, pp. 63-75, 2001.

[27] J. M. Perreault, N. S. Eriksen-Hamel, and J. K. Whalen, “Temporal and spatial dynamics of earthworm surface casting in a temperate soybean agroecosystem," Applied Soil Ecology, vol. 37, no. 1-2, pp. 10-17, 2007.

[28] E. Canada, "National Climate Data and Information Archive," 1971-2000.

[29] E. A. Holland, R. Boone, J. Greenberg, P. M. Groffman, and G. P. Robertson, "Soil CO2, N2O, and CH4 exchange," in Standard
Soil Methods for Longterm Ecological Research, G. P. Robertson, C. S. Bledsoe, D. C. Coleman, and P. Sollins, Eds., pp. 185-201, Oxford University Press, New York, NY, USA, 1999.

[30] G. L. Hutchinson and A. R. Mosier, "Improved cover soil method for field measurement of nitrous oxide fluxes," Soil Science Society of America Journal, vol. 45, pp. 311-316, 1981.

[31] D. G. Maynard, Y. P. Kalra, and J. A. Crumbaugh, "Nitrate and exchangeable ammonium nitrogen," in Soil Sampling and Methods of Analysis, M. R. Carter and E. G. Gregorich, Eds., pp. 71-80, CRC Press, Taylor and Francis, Boca Raton, Fla, USA, 2008.

[32] P. Voroney, P. C. Brookes, and R. P. Beyart, "Soil microbial biomass C, N, P and S," in Soil Sampling and Methods of Analysis, M. R. Carter and E. G. Gregorich, Eds., pp. 637-650, CRC Press, Taylor \& Francis, Boca Raton, Fla, USA, 2008.

[33] M. L. Cabrera and M. H. Beare, "Alkaline persulfate oxidation for determining total nitrogen in microbial biomass extracts," Soil Science Society of America Journal, vol. 57, no. 4, pp. 10071012, 1993.

[34] E. G. Gregorich, M. H. Beare, and M. R. Carter and, "Physically uncomplexed organic matter," in Soil Sampling and Methods of Analysis, M. R. Carter and E. G. Gregorich, Eds., pp. 607-616, CRC Press, Boca Raton, Fla, USA, 2007.

[35] H.-C. Fründ, K. Butt, Y. Capowiez et al., "Using earthworms as model organisms in the laboratory: recommendations for experimental implementations," Pedobiologia, vol. 53, no. 2, pp. 119-125, 2009.

[36] A. C. Elliott and L. S. Hynan, "A SAS macro implementation of a multiple comparison post hoc test for a Kruskal-Wallis analysis," Computer Methods and Programs in Biomedicine, vol. 102, no. 1, pp. 75-80, 2011.

[37] P. Giraudoux, Pgirmess: Data analysis in ecology, in R package version 1.5.8, 2013 .

[38] RC Team, R: A Language and Environment for Statistical Computing, R Foundation for Statistical Computing, Vienna, Austria, 2013.

[39] D. M. Costello and G. A. Lamberti, "Biological and physical effects of non-native earthworms on nitrogen cycling in riparian soils," Soil Biology \& Biochemistry, vol. 41, no. 10, pp. 2230-2235, 2009.

[40] B. K. Paul, I. M. Lubbers, and J. W. Van Groenigen, "Residue incorporation depth is a controlling factor of earthworminduced nitrous oxide emissions," Global Change Biology, vol. 18, no. 3, pp. 1141-1151, 2012.

[41] A. Cierjacks, B. Kleinschmit, I. Kowarik, M. Graf, and F. Lang, "Organic matter distribution in floodplains can be predicted using spatial and vegetation structure data," River Research and Applications, vol. 27, no. 8, pp. 1048-1057, 2011.

[42] J. P. Curry and D. Byrne, "Role of earthworms in straw decomposition in a winter cereal field," Soil Biology and Biochemistry, vol. 29, no. 3-4, pp. 555-558, 1997.

[43] N. B. Hendriksen, "Leaf litter selection by detritivore and geophagous earthworms," Biology and Fertility of Soils, vol. 10, no. 1, pp. 17-21, 1990.

[44] E. R. Suárez, T. J. Fahey, J. B. Yavitt, P. M. Groffman, and P. J. Bohlen, "Patterns of litter disappearance in a northern hardwood forest invaded by exotic earthworms," Ecological Applications, vol. 16, no. 1, pp. 154-165, 2006.

[45] G. Ernst, D. Felten, M. Vohland, and C. Emmerling, "Impact of ecologically different earthworm species on soil water characteristics," European Journal of Soil Biology, vol. 45, no. 3, pp. 207-213, 2009. 
[46] B. Guenet, M. Danger, L. Abbadie, and G. Lacroix, "Priming effect: bridging the gap between terrestrial and aquatic ecology," Ecology, vol. 91, no. 10, pp. 2850-2861, 2010.

[47] J. M. H. Knops, K. L. Bradley, and D. A. Wedin, "Mechanisms of plant species impacts on ecosystem nitrogen cycling," Ecology Letters, vol. 5, no. 3, pp. 454-466, 2002.

[48] A. B. Speratti and J. K. Whalen, "Carbon dioxide and nitrous oxide fluxes from soil as influenced by anecic and endogeic earthworms," Applied Soil Ecology, vol. 38, no. 1, pp. 27-33, 2008. 

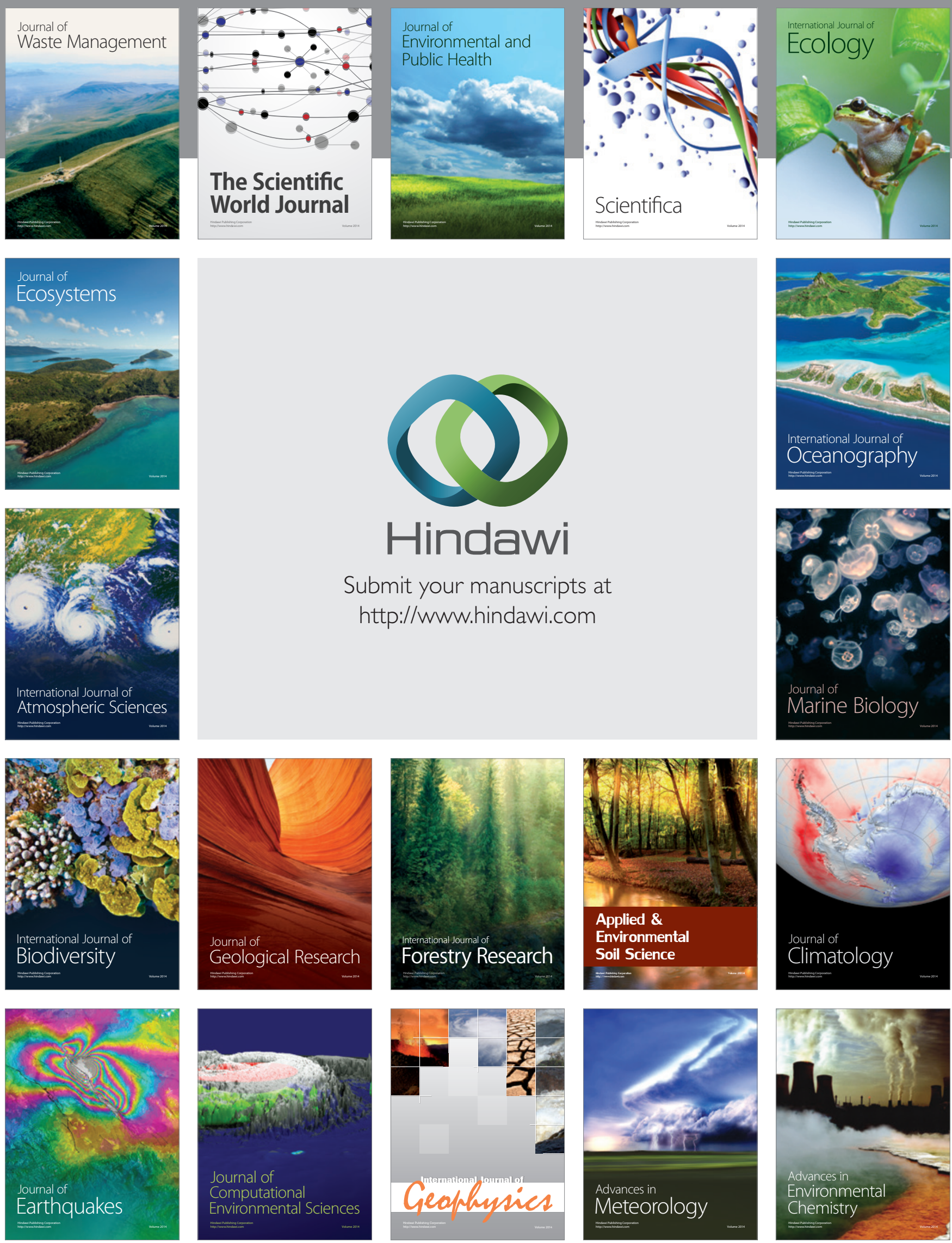